\title{
Incidence and distribution in sorghum of the spotted stem borer Chilo partellus and associated natural enemies in farmers' fields in Andhra Pradesh and Maharashtra states
}

(Keywords: Chilo partellus, sorghum, parasitoids, intercropping, Maharashtra, Andhra Pradesh)

\author{
A. H. DUALE* and K. F. NWANZE
}

International Crops Research Institute for the Semi-Arid Tropics (ICRISAT), Patancheru 502 324, Andhra Pradesh, India

\begin{abstract}
A series of surveys was carried out in farmers' fields in two major sorghum-growing states of India (Maharashtra and Andhra Pradesh) during the 1994 and 1995 cropping seasons to determine distribution, abundance, and economic importance of the spotted stem borer Chilo partellus Swinhoe and associated parasitoids in sorghum. Stem borer incidence and distribution varied significantly between the two states. In Maharashtra, the highest incidence was recorded in Amravati district (40\%), followed by Yavatmal (39\%). In Andhra Pradesh, the highest incidence and damage were recorded from Medak (31\%), followed by Mahbubnagar (30.3\%). The natural enemies recorded in the survey included three larval parasitoids, viz. Cotesia ruficrus (Haliday) and $C$. flavipes Cameron, and Sturmiopsis inferens Townsend and one pupal parasitoid Xanthopimpla stemmator Thunberg. While species composition did not vary between the two states, species predominance varied considerably, such that Cotesia spp. were predominant in Maharashtra, and S. inferens in Andhra Pradesh.
\end{abstract}

\section{Introduction}

Sorghum (Sorghum bicolor (L.) Moench) is one of the major cereal crops in India, occupying an area of 16 million hectares with a total production of 11 million tons (Gahukar and Jotwani, 1980). Because of the broad genetic diversity in the local landrace cultivars, sorghum grows under a wide range of agroecological conditions, and more than $95 \%$ of the total sorghum is produced by subsistence farmers (Doggett, 1982; Mann et al., 1983). Among the important states with sizeable hectarage are Maharashtra and Andhra Pradesh. Production in Maharashtra has increased from 3.5 million metric tonnes in 1975 to 4.6 million metric tonnes in 1994 (23.9\% increase), this has been the result of the introduction of high yielding hybrid cultivars, and also partially accounts for the reduced area cultivated to sorghum in that state (from 6.2 million ha to 5.4 million ha) over the same period.

Because of changes in cultivation practices and in maturity patterns of the improved cultivars, susceptibility of sorghum to insect pests has increased. For example, all currently grown hybrids and improved varieties of sorghum are highly susceptible to sorghum midge, Stenodiplosis (=Contarinia) sorghicola Coquillett (Diptera: Cecidomyiidae) (Sharma, 1993). The estimated loss of sorghum to insect pests throughout India has been reported by Gahukar and Jotwani (1980) as $15-20 \%$. This figure applies mostly to the sorghum shoot fly Atherigona soccata Rondani, and midge for which loss estimates have been obtained at research stations. Very little information exists for stem borers. A rapid on-line search in the International Crops Research Institute for the Semi-Arid Tropics (ICRISAT) Library of SATCRIS, AGRIS, and AGRICOLA databases between 1975 and 1995, revealed there to be over 180 published articles on Chilo partellus in India. Only five of these report on the seasonal occurrence of this pest. Although $C$. partellus is considered to be among the most damaging pests of sorghum crop throughout the world (Jepson, 1954; Harris, 1962; Seshu Reddy, 1988) and grain losses due to $C$. partellus ranging between 2 and $88 \%$ in sorghum have been recorded (Seshu Reddy, 1988), these studies were conducted in research stations and no information was provided on borer incidence and damage in farmers' fields.

Adequate knowledge of the incidence, distribution and economic importance, and farmers' perception of an insect is pivotal both in determining its pest status and in the development of a research agenda targeted towards viable management options. Information on pest incidence and distribution needs to be substantiated for clear and directed research planning. Compilation of such information requires accumulation of quantitative data through diagnostic on-farm assessment of pest incidence, associated natural enemies, crop damage and losses, with direct farmer participatory inputs. Periodic review of such an information base is then necessary to ensure a proper focus on research on the target species. ICRISAT has initiated an extensive data collection on pest and associated natural enemies incidence and distribution in its mandate regions in Africa and Asia through compilation of existing information, additional farm surveys, farmer interviews, diagnostic on-farm studies of crop damage and farmers' perception of pests and pest damage. This paper reports the results from such activity conducted in India for sorghum stem borer in the two major sorghum-growing states of Maharashtra and Andhra Pradesh.

Farm surveys were conducted during 1994 and 1995 rainy and post-rainy seasons by a multidisciplinary team of ICRISAT scientists in collaboration with scientists from the Indian national research stations and non-governmental organizations (NGOs). 


\section{Materials and methods}

Ten survey tours covering 300 villages and 352 fields were undertaken during the cropping seasons between February 1994 and August 1995 in three districts in Andhra Pradesh (Medak, Rangareddy, and Mahbubnagar) and six districts in Maharashtra (Akola, Amravati, Buldana, Nagpur, Wardha, and Yavatmal). These districts fall into three agro-ecological zones, namely zone $\mathrm{VI}$ in Andhra Pradesh and zones $\mathrm{VI}$ and $\mathrm{X}$ in Maharashtra (table 1 and figure 1). Surveys were extensive and were conducted to coincide with farmers' crops at $4-6$ weeks after sowing.

Fields were selected at random at about $10-15 \mathrm{~km}$ intervals, depending on their distribution, road accessibility and area to be covered during a particular survey. In addition to farmers' fields a number of offices of the Directorate of Agriculture and regional Agricultural Research Stations were visited and discussions held with resident personnel on the situation of sorghum insect pests in their respective districts.
Depending on farm size and plant population, between 100 and 300 plants per field were sampled and examined for stem borer incidence and damage. Stem borer leaf feeding damage was scored on a 1-9 scale, based on plants showing leaf feeding symptoms where $1=1-2$ leaves with feeding symptoms per plant and $9=5-6$ leaves per plant with feeding symptoms (Sharma et al., 1992).

For estimating natural enemy activity, efforts were made to obtain large samples of stem borers so that significant numbers of parasitoid (individuals, species) could be reared and percentage parasitism could be adequately estimated. Samples $(20-30)$ of infested stems were dissected in farmers' fields and all the stem borer larvae/pupae collected into corked glass tubes. Larvae were fed with fresh stem pieces of sorghum stems and examined daily for adult parasitoid or borer moth emergence. Identification to species level was done on completion of parasitoid emergence using reference collections in the central insect museum at ICRISAT Asia Centre. In addition, farmers' name, farm size, crop cultivar, sowing date, soil type and

Table 1. Agro-ecological zones of Maharashtra and Andhra Pradesh

\begin{tabular}{|c|c|c|c|c|c|}
\hline Medak & VI (AES 7.2) & NA & $1803^{\prime}$ & $7816^{\prime}$ & 783 \\
\hline Rangareddy & VI (AES 7.2) & 545 & $1727^{\prime}$ & $7800^{\prime}$ & 764 \\
\hline Akola & VI (AES 6.3) & 282 & $2042^{\prime}$ & $7702^{\prime}$ & 878 \\
\hline Amravati & VI (AES 6.3) & 370 & $2056^{\prime}$ & $7747^{\prime}$ & 976 \\
\hline Buldana & VI (AES 6.3) & 650 & $2032^{\prime}$ & $7611^{\prime}$ & 901 \\
\hline Yavatmal & VII (AES 6.3) & 451 & $2032^{\prime}$ & $7808^{\prime}$ & 1130 \\
\hline
\end{tabular}

Source: National Bureau of soil survey and landuse planning, ICAR, Nagpur 440 010, India.

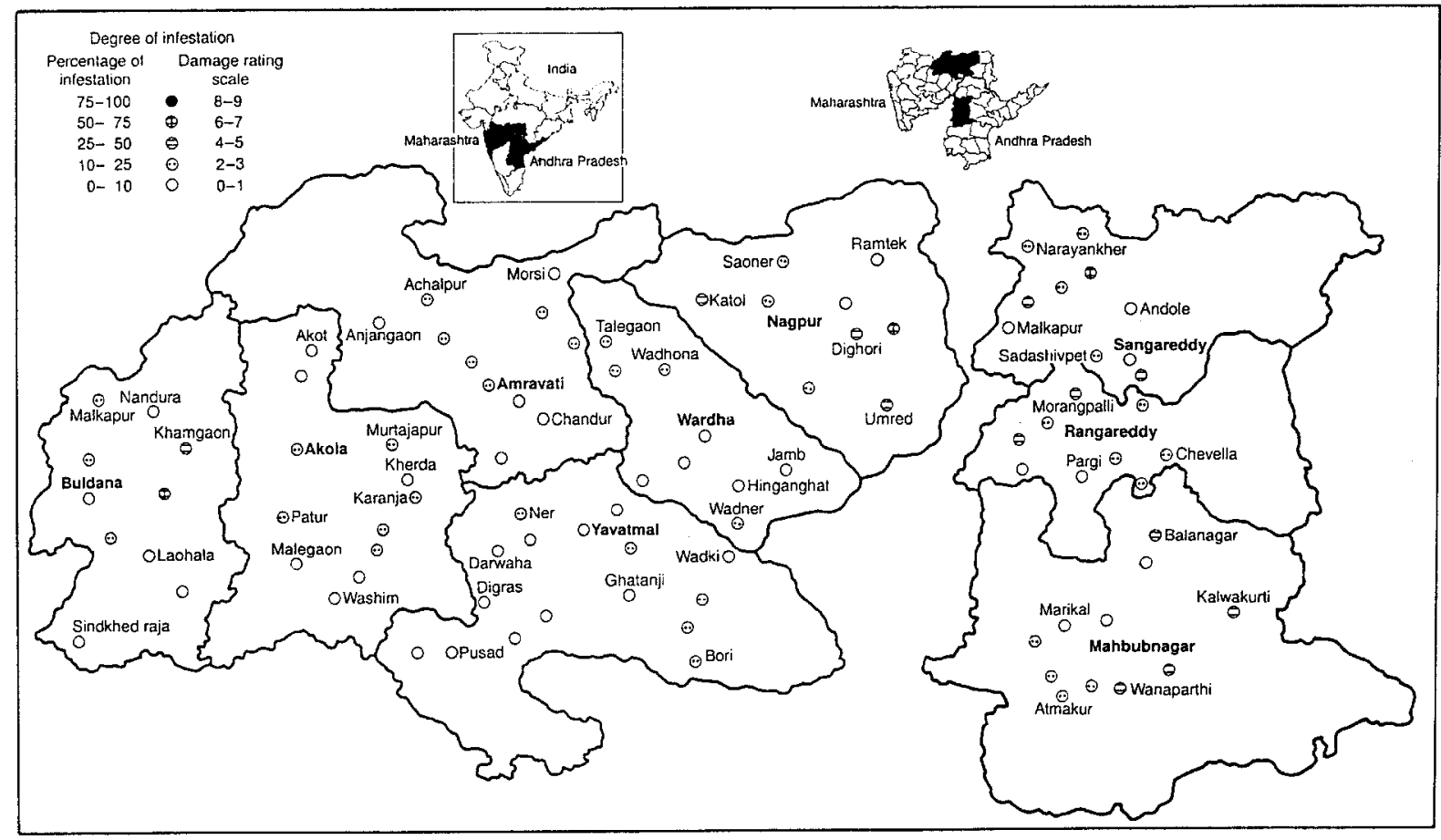

Figure 1. Distribution of the spotted stem borer C. partellus during 1994 and 1995 field surveys in Andhra Pradesh and Maharashtra, India. 
farmers' perception about insect pests and their damage/control measures were recorded. Data collected on the incidence of $C$. partellus and its associated natural enemies at the field site level were pooled to obtain district averages, and the latter further pooled to obtain state averages. Field site data were also used to classify damage severity. The information was used to develop pest distribution maps for Andhra Pradesh and Maharashtra.

Data on the incidence and distribution of the pest and its natural enemies were subjected to ANOVA using general linear models (SAS Institute, 1985). Significant differences in means between states were separated using the Least Significant Difference Test (LSD) at a probability level of $5 \%(P=0.05)$.

\section{Results and discussion}

\subsection{Cropping pattern}

The cropping pattern in Andhra Pradesh and Maharashtra varied from monoculture to various intercropping or mixed cropping systems. In addition to sorghum, maize, rice, pigeonpea, cowpea, mungbeans, sugarcane, groundnut, and millet were grown.

Of the 352 farmers' fields surveyed, sorghum was grown as a monoculture in 196 farms (55.7\%), and, in the rest, was intercropped/mixed with either pigeonpea, cowpea, mungbeans, or millet. At individual state level, 56 farms (45.2\%) of the 124 fields surveyed in Andhra Pradesh had sorghum as the sole crop. By contrast, 140 farms (61.4\%) of the 228 farmers' fields surveyed in Maharashtra had sorghum grown as the sole crop.

In general, a high proportion (>95\%) of the fields in Maharashtra was cropped with a commercial hybrid, CSH 9. Planting was usually in rows with optimum plant densities (150 000 plants ha $^{-1}$ ). By contrast, in Andhra Pradesh, the local genotype (Pachcha) was predominant (>90\%). When planted in high densities (130000 plants ha ${ }^{-1}$ ), the crop appeared tall, and thin-stemmed with small compact heads. However, at low densities (80 000 plants $\mathrm{ha}^{-1}$ ) and in fertile soils, the crop appeared tall with loose heads.
Farmers interviewed in Andhra Pradesh villages preferred local genotypes which gave better fodder yields than hybrids. Farmers also indicated that they were unable to afford the purchase of seeds, fertilizer, pesticides and farm operations associated with hybrids.

\subsection{Pest observations}

3.2.1. Influence of cropping pattern on stem borer incidence. The relative abundance of the stem borer varied with season, sowing date, crop management and crop variety. In Maharashtra, stem borer incidence varied between 26.4\% in Akola and $40 \%$ in Amravati with a state level mean of $32.4 \%$. Stem borer infestation in Andhra Pradesh varied from 28.2\% in Rangareddy to $31 \%$ in Medak with a state level mean of $29.8 \%$ (table 2). Stem borer incidence and distribution did not vary significantly between the two states.

Stem borers were present in all of the sorghum fields in Andhra Pradesh and $97.9 \%$ in Maharashtra, but only $23.4 \%$ of the 19543 stems examined in Andhra Pradesh and 27.5\% of the 25713 stems examined in Maharashtra exhibited stem tunnelling and stem breakage. Grain filling of heads was hardly affected.

Stem borer incidence was low (6.7\%) where sorghym was intercropped with legumes but increased to $24.8 \%$ (a 3.7 -fold increase) in sole-crop sorghum fields in Rangareddy. In Maharashtra, infestation increased by 2.6 -fold in Akola and by 3-fold in Buldana in sole crop sorghum compared with mixed/ intercropped sorghum (table 2). Stem borer infestation did not vary significantly between the districts in the two states of Maharashtra and Andhra Pradesh except where sorghum was grown as the sole crop (table 2). However, the stem borer infestation varied significantly within the districts in Maharashtra (figure 2).

Sorghum sole crop had significantly higher stem borer infestation compared with mixed or intercropped systems and the highest stem borer infestation was recorded from Yavatmal with an average infestation level of $25.7 \%$ in sorghum sole crop, followed by Amravati with $25.4 \%$ stem borer infestation (table 2).

Table 2. Incidence and distribution of the stem borer Chilo partellus Swinhoe in Andhra Pradesh and Maharashtra

\begin{tabular}{|c|c|c|c|c|c|}
\hline \multirow[b]{2}{*}{ District } & \multirow[b]{2}{*}{ No. of farms surveyed } & \multirow[b]{2}{*}{$\%$ farms infested } & \multicolumn{3}{|c|}{ Mean percentage borer incidence } \\
\hline & & & District mean & Monocrop sorghum & Inter/mix crop sorghum \\
\hline \multicolumn{6}{|c|}{ ANDHRA PRADESH } \\
\hline Medak & 38 & 100.0 & $31.0 \pm 3.5 \mathrm{a}$ & $19.7 \pm 3.5 \mathrm{a}$ & $11.3 \pm 2.4 \mathrm{a}$ \\
\hline Rangareddy & 38 & 100.0 & $28.2 \pm 5.5 \mathrm{a}$ & $24.8 \pm 6.1 \mathrm{a}$ & $6.7 \pm 6.1 \mathrm{a}$ \\
\hline Mahbubnagar & 46 & 100.0 & $30.3 \pm 9.3 a$ & $21.6 \pm 6.2 \mathrm{a}$ & $8.7 \pm 3.2 \mathrm{a}$ \\
\hline State mean & 124 & 100.0 & $29.9 \pm 3.3 \mathrm{a}$ & $22.1 \pm 3.1 \mathrm{a}$ & $8.9 \pm 1.4 \mathrm{a}$ \\
\hline \multicolumn{6}{|l|}{ HARASHTRA } \\
\hline Akola & 40 & 95.0 & $36.4 \pm 7.8 b$ & $18.9 \pm 6.0 \mathrm{~b}$ & $7.4 \pm 1.8 \mathrm{ab}$ \\
\hline Amravati & 32 & 100.0 & $40.0 \pm 10.1 \mathrm{a}$ & $25.4 \pm 5.4 \mathrm{a}$ & $14.6 \pm 4.8 \mathrm{a}$ \\
\hline Buldana & 42 & 100.0 & $28.2 \pm 10.4 b$ & $21.1 \pm 5.4 \mathrm{ab}$ & $6.9 \pm 5.8 b$ \\
\hline Nagpur & 30 & 100.0 & $30.9 \pm 4.5 \mathrm{ab}$ & $17.9 \pm 2.7 b$ & $13.0 \pm 2.9 \mathrm{ab}$ \\
\hline Wardha & 30 & 100.0 & $29.8 \pm 10.4 \mathrm{ab}$ & $22.1 \pm 5.6 \mathrm{ab}$ & $7.6 \pm 6.1 \mathrm{ab}$ \\
\hline Yavatmal & 54 & 92.59 & $39.1 \pm 11.7 \mathrm{a}$ & $25.7 \pm 7.8 \mathrm{a}$ & $13.4 \pm 4.7 \mathrm{ab}$ \\
\hline State mean & 228 & 97.93 & $32.4 \pm 3.5 \mathrm{a}$ & $21.8 \pm 2.1 \mathrm{ab}$ & $10.5 \pm 1.8 \mathrm{a}$ \\
\hline
\end{tabular}

Means in the same column followed by different letters are significantly different at $5 \%$ level. 
3.2.2. Incidence of larval and pupal parasitoids on Chilo partellus. The natural enemies of sorghum stem borer found during the survey included three larval parasitoids Cotesia ruficrus (Haliday) and C. flavipes (Cameron) (Hymenoptera: Braconidae), and Sturmiopsis inferens (Townsend) (Diptera: Tachinidae)) and one pupal parasitoid Xanthopimpla stemmator (Thunbery) (Hymenoptera: Ichneumonidae). The survey results show that braconids and tachnids achieved a higher level of
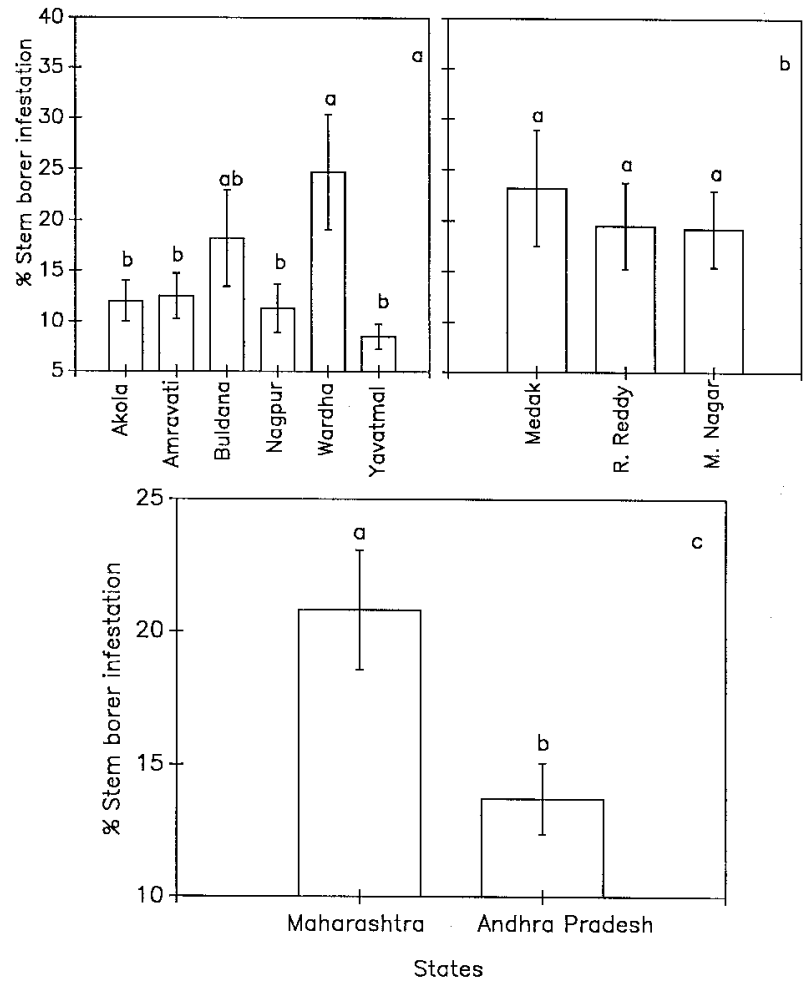

Figure 2. Stem borer infestation of sorghum in Andhra Pradesh and Maharashtra. parasitism than ichneumonids, and that $C$. ruficrus reported previously on Mythimna separata (Gahukar and Jotwani, 1980), had become a prominent member of the parasitoid complex on Chilo partellus.

Only one species of pupal parasitoid, X. stemmator, was recorded from Maharashtra and Andhra Pradesh. C. partellus pupal parasitism was significantly lower in Andhra Pradesh than in Maharashtra and the highest pupal parasitism in Andhra Pradesh (26.2\% in Medak) was lower than the lowest $(30.2 \%$ in Nagpur) in Maharashtra (tables 3 and 4).

Although species composition did not vary between the two states, species predominance varied considerably, such that in Andhra Pradesh, a higher percentage of larval parasitoids was reared from $C$. partellus than pupal parasitoids. In Maharashtra, the percentage of pupal parasitoids reared was higher than for larval parasitoids (tables 3 and 4).

\section{Conclusion}

The survey indicates that the spotted stem borer problems in traditional low-input systems do not appear to be severe. However, it should be noted that insect pest situations are dynamic processes and changes in climate and farming practices and the introduction of improved varieties have been known to result in pest outbreaks or changes in pest status (Nwanze, 1988).

The distribution and relative abundance of $C$. partellus in Andhra Pradesh and Maharashtra is thought to be influenced by two main factors: (1) the minimum temperature, which in most areas is a reflection of the altitude, and (2) the occurrence and severity of the dry season. The possibility that temperature might be a limiting factor influencing the distribution of $C$. partellus in India was first suggested by Butani (1955). Similarly, Wellington and Trimble (1984) reported that the number of parasitized hosts, the parasitoid immature development and sex ratio were influenced by

Table 3. Incidence of larval and pupal parasitoids of Chilo partellus (Swinhoe.) on sorghum under natural infestation in farmers' fields in Andhra Pradesh

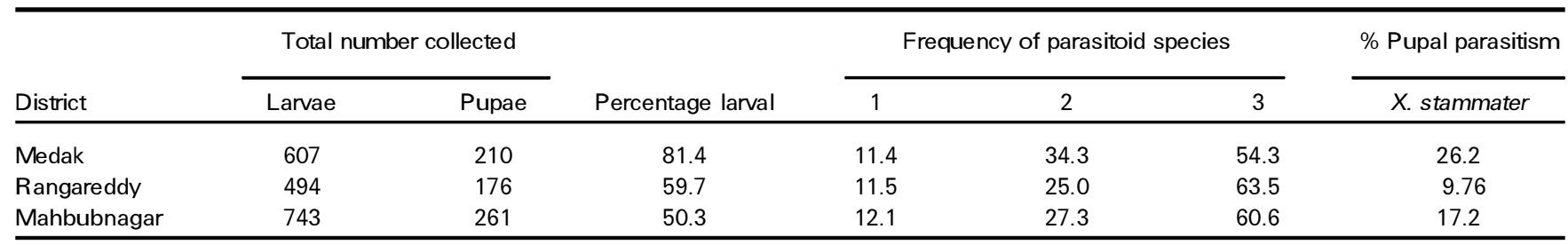

1. Cotesia flavipes; 2. Cotesia ruficrus; 3 . Stermiopsis inferens.

Table 4. Incidence of larval and pupal parasitoids of Chilo Partellus (Swinhoe.) on sorghum under natural infestation in farmers' fields in Andhra Pradesh

\begin{tabular}{|c|c|c|c|c|c|c|c|}
\hline \multirow[b]{2}{*}{ District } & \multicolumn{2}{|c|}{ Total number collected } & \multirow[b]{2}{*}{ Percentage larval } & \multicolumn{3}{|c|}{ Frequency of parasitoid species } & \multirow{2}{*}{$\frac{\% \text { pupal parasitism }}{\text { X. Stammater }}$} \\
\hline & Larvae & Pupae & & 1 & 2 & 3 & \\
\hline Amravati & 250 & 54 & 44.8 & 57.1 & 19.1 & 23.8 & 38.9 \\
\hline Buldana & 203 & 61 & 72.4 & 55.0 & 25.0 & 20.0 & 36.1 \\
\hline Nagpur & 138 & 86 & 27.5 & 36.8 & 15.8 & 47.4 & 30.2 \\
\hline
\end{tabular}

1. Cotesia flavipes; 2. Cotesia ruficrus; 3 . Stermiopsis inferens. 
climatic factors associated with latitude and/or altitude. It would appear that species predominance could partially be associated with latitude. C. ruficrus occurred below latitude $20^{\circ} 32^{\prime}$ corresponding with areas in Andhra Pradesh and C. flavipes occurred above latitude $18^{\circ} 03^{\prime}$ corresponding with areas in Maharashtra (table 1). Most parasitoids recorded in this study are indigenous to Asia and their association with $C$. partellus is long-standing. They are probably more habitat-specific than host-specific. Cotesia flavipes, $C$. ruficrus and $S$. inferens have been recorded from Chilo sp. Sesamia sp., Eldana sccharina, and Diatrea sp. (Descamps, 1956; Schmutterer, 1969; Appert, 1971; Breniere, 1977; Breniere et al., 1985; Smith et al., 1992). However, X. stemmator, in addition to Chilo, Sesamia and Eldana sp., has been recorded from Cryptophlebia rhynchias (Anon. (CIBC), 1977; Nikam and Basarker, 1981; Kfir, 1991; 1992).

Our survey data clearly show that natural enemies are closely associated with sorghym stem borers in farmers' fields at all levels of infestation. However, the levels of infestation were higher in farmers' fields than have been recorded on the ICRISAT research farm (Nwanze et al., 1995). The variation in levels of parasitism has been attributed partly to differences in varietal cultivation, latitude, and climate between the two states. This merits further investigation since it provides a potential area of interaction between host plant resistance and biological control IPM strategies. By implication, because the level of borer resistance in improved genotypes is still very low (Nwanze, 1997), breeding sorghum genotypes which will enhance natural enemy activity could be a new strategic approach in borer management.

\section{Acknowledgements}

We thank K. Hareendranath and J. Raja Rao for their technical assistance in the field. This paper was approved as Journal article No. 1920 by the International Crops Research Institute for the Semi-Arid Tropics (ICRISAT).

\section{References}

ANON. (CIBC). 1997. Biological control of lepidopterous stem borers of tropical graminaceous crops. Status Paper. Commonwealth Institute of Biological Control, 12pp.

APPERT, J., 1971. Les lepidopteres foreus des graminees a Madagascar, aux Comores et aux Mascareignes. Agronomie Tropicale, 24, 500-508.

APPERT, J., 1973. Entomofauna parasitaire des foreurs des graminees a Madagascar. Entomophaga, 18, 77 - 94.

BRENIERE, J., 1977. Etude des possibilities de Concertation en matiere de lutte biologique et integree. Reunion sur les foreurs des graminees. Bnouake, Cote d'lvoire, 8- 11 November, Annexe III, 13pp.

BRENIERE, J., BORDAT, D., VERCAMBRE, B., HAMZA, H. and RENAND, M., 1985. Less operations du lutte biologique contre le foreur du mais Chilo partellus (Swinhoe), (Lepidoptera: Pyralidae) dans l'ile de ngazidja. Agronomie Tropicale, 40(2), $157-166$.
BUTANI, D.K., 1955. The influence of temperature on the development of insects, with special reference to Chilo zonellus. Indian Journal of Entomology, 17, 280-282.

DESCAMPS, M., 1956. Insects nuisibles auriz dans le Nord Cameroun. Agronomie Tropicale, 11, $732-755$.

DOGGETT, H., 1982. Sorghum improvement in east Africa. In A. Leaky (ed) Crop Improvements in East Africa (Farnham Roya, UK: Commonwealth Agricultural Bureaux), pp. 60-87.

GAHUKAR, R.T. and JOTWANI, M.G., 1980. Present status of field pests of sorghum and millet in India. Tropical Pest Management, 26 (2),138- 151.

HARRIS, K.M., 1962. Lepidopterous stem borers of cereals in Nigeria. Bulletin of Entomological Research, 53, $138-172$

JEPSON, W.F., 1954. A Critical Review of the World Llterature on the Lepidopterous Stalk Borers of Tropical Graminaceous Crops (London: Commonwealth Institute of Entomology), pp. 1 - 128.

KFIR, R., 1991. Non-chemical control of grains. Plant Protection News; Bulletin of the Plant Protection Research Institute (Pretoria, South Africa), March 1991, 23, p4.

KFIR, R., 1992. Selecting parasites for biological control of lepidopterous stalk borers in summer grain crops in South Africa. Redia, 74 (3), 231 - 236.

MANN, J. A., KIMBER, C.T. and MILLER F.R., 1983. The origin and early cultivation of sorghum in Africa. Bull. 1454, Texas A\&MUniversity, College Station, Texas, USA, $21 \mathrm{pp}$.

NIKAM, P.K. and BASARKAR, C.D., 1981. Life tables and intrinsic rate of increase of Xanthopimpla stemmator Thunberg (Hymenoptera: Ichneumonidae) population on Chilo partellus pupae. Insect Science and its Application, 2, 209-212.

NWANZE, K.F., 1988. Distribution and seasonal incidence of some major insect pests of sorghum in Burkina Faso. Insect Science and its Application, 9 (3), $313-321$.

NWANZE, K.F., 1997. Integrated management of stem borers of sorghum and pearl millet. Insect Science and its Application 17 (1), 1-8.

NWANZE, K.F., DUALE, A.H., KAUSALYA, K.G. and REDDY, Y.V.R., 1995. Host plant-insect-parasitoid interactions in sorghum: case studies with midge (Contarinia sorghicola) and stem borer (Chilo partellus) and implications in resistance breeding. Insect Pest Control for Smallholders in Africa, Integrating Host Plant Resistance and Biological Control Seminar. CTA-IAR-IIBC Seminar, Addis Ababa, 9-14 October, 1995.

SAS INSTITUTE, 1985. SAS Users' Guide: Statistics, Version 5 (Cary, North Carolina: SAS Institute), 956pp.

SCHMUTteRER, G., 1969. Pests of Crops in Northwest and Central Africa, with Particular Reference to the Sudan. (Stuttgart: Fischer Verlag) 296pp.

SESHU REDDY, K.V., 1988. Assessment of on-farm yield losses in sorghum due to insect pests. Insect Science and its Application, 9, 679-685.

SHARMA, H.C., 1993. Host-plant resistance to insects in sorghum and its role in integrated pest management. Crop Protection, 12 (1), 11 - 34.

SHARMA, H.C., TANEJA, S.L., LEUSCHNER, K. and NWANZE, K.F., 1992. Techniques to screen sorghum for resistance to insect pests. Information Bulletin no. 32 (Patancheru, A.P. 502 324, India: International Crops Research Institute for the Semi-Arid Tropics), 48pp.

SMITH, J.W. JR, WIEDENMANN, R.N. and OVERHOLT, W.A., 1992. Parasites of Lepidopterous Stalk Borers of Tropical Graminaceous Plants (Nairobi, Kenya: ICIPE Science Press), pp. $1-89$.

WELLINGTON, W.G. and TRIMBLE, R.M., 1984. Weather. In C. B. Huffaker and R. L. Rabb (eds) Ecological Entomology (New York: Wiley), pp. 421 425 . 